\title{
Treating anal fistula with the anal fistula plug: case series report of 12 patients
}

Reza Bagherzadeh Saba ${ }^{1}$, Adnan Tizmaghz², Somar Ajeka ${ }^{3}$, Mehdi Karami ${ }^{2}$

\author{
${ }^{1}$ MD., Assistant Professor of Colorectal Surgery, Rasool-e-Akram Hospital, Iran University of Medical Sciences, \\ Tehran, Iran \\ ${ }^{2}$ MD., Resident of General Surgery, Rasool-e-Akram Hospital, Iran University of Medical Sciences, Tehran, Iran \\ ${ }^{3}$ MD., Assistant Professor of Colorectal Surgery, Damascus University of Medical Sciences, Damascus, Syria
}

Type of article: Case series report

\begin{abstract}
Introduction: Recurrent and complex high fistulas remain a surgical challenge. This paper reports our experience with the anal fistula plug in patients with complex fistulas.

Methods: Data were collected prospectively and analyzed from consecutive patients undergoing insertion of a fistula plug from January 2011 through April 2014 at Hazrat-e-Rasoul Hospital in Tehran. We ensured that sepsis had been eradicated in all patients prior to placement of the plug. During surgery, a conical shaped collagen plug was pulled through the fistula tract.

Results: Twelve patients were included in this case study. All patients had previously undergone failed surgical therapy to cure their fistula and had previously-placed Setons. There were eight males and four females with an average age of 44 who were treated for complex fistulas. At a median time of follow-up of 22.7 months, 10 of the 12 patients had healed $(83.3 \%)$. One patient developed an abscess that was noted on the sixth postoperative day, and there was one recurrence during follow-up.
\end{abstract}

Conclusions: Fistula plugs are effective for the long-term closure of complex anal fistulas. Success of treatment with the fistula plug depends on the eradication of sepsis prior to plug placement.

Keywords: anal fistula, treating, fistula plug

\section{Introduction}

Anal fistula is a debilitating disease that requires complicated medical interventions to treat the patients (1). According to the studies, the incidence of fistula-in-ano ranges from $26-38 \%$ (2). Its prevalence has not been exactly defined, but a few studies have reported its prevalence in limited populations (3). The condition may occur subsequent to several conditions, including Crohn's disease, previous anorectal abscess, trauma (e.g., rectal foreign bodies), anal fissures, carcinoma, radiation therapy, actinomycoses, tuberculosis, and lymphogranuloma venereum secondary to chlamydial infection (3-5). Therapeutic options include several surgical and non-surgical interventions. Recently, successful application of stem cell therapy for complex anal fistulas has been reported $(6,7)$. However, the success rate of current interventions is limited by the recurrence of fistula in patients treated by surgical approaches, and stem cell therapy for this condition is still in its beginning. Also, the results from a phase III, randomized, controlled trial have demonstrated no advantage of stem cell therapies over fibrin glue alone (6). Surgical intervention is indicated for symptomatic patients with recurrent anorectal sepsis and Crohn's disease with multiple and often complex fistulas (4). As surgical intervention is sometimes associated with sphincter damage, it may cause fecal incontinence and decreased quality of life in patients who undergo surgery (8). However, sphincter-saving surgical approaches have shown great promise for the improvement of outcomes. These approaches include fibrin glue (9-11), loose seton placement (8), and anal fistula plug insertion (5). Several studies have reported successful application of fistula plugs in the closure of high anal fistulas, although they suggested that further investigations are required to obtain conclusive evidence (12-14). None of the current techniques for the treatment of high fistulae

\section{Corresponding author:}

Adnan Tizmaghz, Rasool-e-Akram Hospital, Iran University of Medical Sciences, Tehran, Iran.

Tel: +98.64352215, E-mail: adnan_ti@yahoo.com

Received: September 11, 2015, Accepted: February 06, 2016, Published: April 2016

iThenticate screening: February 05, 2016, English editing: March 22, 2016, Quality control: April 02, 2016

(C) 2016 The Authors. This is an open access article under the terms of the Creative Commons Attribution-NonCommercialNoDerivs License, which permits use and distribution in any medium, provided the original work is properly cited, the use is non-commercial and no modifications or adaptations are made. 
produces reliable healing rates, and all are associated with varying degrees of incontinence. The current Fistula-InAno trial (FIAT) trial in the UK by L. Magill along with the $14 \%$ success from the Cleveland Clinic compares these existing treatments to the use of a bioprosthetic plug derived from pig intestines. Evidence of the efficacy of this treatment is limited, and the trial attempts to provide more information on both efficacy and cost-effectiveness. In line with these studies, we tried to implement the application of fistula plugs for treating high anal fistulas in our Center, and we evaluated the results of the insertion of the anal fistula plug on several outcomes of the surgical operation intended to treat high anal fistulas in sphincter-saving fashion. In the current study, first, results from Iranian patients are described.

\section{Material and methods}

In this case study, 12 symptomatic patients suffering from high anal fistula were referred to the Department of Surgery at Hazrat-e-Rasoul Hospital in Tehran, which is a major referral center for colon and rectal surgery. These patients were enrolled in the study from January 2011 through April 2014. All patients were of non-Crohn's disease background. In addition, this study was approved by the Medical Research Ethics Committee, and informed consent was obtained from all of the patients. The patients underwent intent-to-treat surgical operation for insertion of the fistula plug. All surgical operations were performed by the same colorectal surgeon. The surgical procedure was performed as described by Ommer et al. (5). We assured sepsis had been eradicated in all of the patients prior to plug placement. During surgery, the fistula tract and the internal opening were identified. A collagen, cone-shaped plug was pulled into the fistula tract. The fistula plug portion that remained outside the tract was removed. The plug was fixed by vicryl 2-0 stitches. The operation was considered successful if the external opening was closed and drainage was totally stopped at the last follow-up visit.

\section{Results}

Twelve patients were studied, i.e., eight males and four females. The mean age of the patients was 44 (SD: 42.7), ranging from 27 to 62 years. Among the 12 patients, one patient developed an abscess in the fistula where the plug was placed. The abscess was drained, and the plug was removed. Fistula recurred in one of the patients after spontaneous expulsion of the plug. Two patients $(16.6 \%)$ had recurrence or the treatment with the fistula plug failed. Three patients complained about secretions after the fistula plug was inserted. The symptoms ameliorated in these patients over time. These patients recovered completely after daily changes of the bandage and care for the wound. No recurrence was observed in these patients. Other complications, such as fecal incontinence, gas incontinence, regional allergy, and severe pain were not observed in any of the patients. Complete data of the patients enrolled in this study are available in Table 1.

Table 1. Characteristics of the patient population studied in the current research and the outcome measures

\begin{tabular}{|l|l|l|l|l|l|l|}
\hline $\begin{array}{l}\text { Patient } \\
\text { code }\end{array}$ & Gender & $\begin{array}{l}\text { Age } \\
\text { (years) }\end{array}$ & $\begin{array}{l}\text { Duration of } \\
\text { sickness (months) }\end{array}$ & $\begin{array}{l}\text { Number of previous } \\
\text { interventions }\end{array}$ & $\begin{array}{l}\text { Time of follow } \\
\text { up (months) }\end{array}$ & $\begin{array}{l}\text { Recurrence of } \\
\text { fistulas }\end{array}$ \\
\hline 1 & Male & 28 & 16 & 2 & 30 & - \\
\hline 2 & Male & 57 & 12 & 1 & 18 & - \\
\hline 3 & Male & 36 & 8 & 1 & 10 & - \\
\hline 4 & Male & 62 & 20 & 2 & 18 & - \\
\hline 5 & Male & 37 & 17 & 2 & 3 & - \\
\hline 6 & Male & 27 & 30 & 3 & 33 & - \\
\hline 7 & Male & 46 & 21 & 2 & 2 & + \\
\hline 8 & Male & 40 & 36 & 4 & 24 & - \\
\hline 9 & Female & 37 & 12 & 2 & 28 & - \\
\hline 10 & Female & 62 & 19 & 3 & 36 & - \\
\hline 11 & Female & 36 & 15 & 2 & 18 & - \\
\hline 12 & Female & 60 & 24 & 3 & 12 & - \\
\hline
\end{tabular}

\section{Discussion}

Treatment of anal fistulas has remained a perplexing medical challenge. While surgical operation is indicated for the treatment of high fistula-in-ano, several modifications to this method have been made to improve the success rate of surgical interventions. One surgical approach includes insertion of fistula plugs into the fistula, which has sparked significant interest among colorectal surgeons. The Gore BioA fistula plug has been studied extensively for the closure of anal fistula, and it has demonstrated success in these operations. In the current study, we used a surgical 
operation for insertion of the Gore BioA fistula plugs to treat perianal high trans-sphincteric fistula-in-ano in patients receiving this treatment at Hazrate Rasoole Akram Hospital in Tehran, Iran. Our study indicated a high success rate for the method in the closure of fistula tract in patients who had experienced unsuccessful surgical interventions earlier for the treatment of complex anal fistulas. The results of our study showed a high success rate for high anal fistula treatment by insertion of a Gore BioA fistula plug. This is consistent with the results from German studies by Ommer et al. and Ratto et al. $(5,15-17)$. Their studies showed that high anal fistula closure by plug is a simple, effective, and safe technique that is applicable for the treatment of most patients who have had previous unsuccessful surgical intervention for the treatment of fistula-in-ano. While our study only includes nonCrohn's disease patients, their study examined a mixture of patients and demonstrated the significant effects of the plug insertion in Crohn's patients as well. In addition, the Gore BioA fistula plug seems to be more effective than fibrin glue closure, as evidenced in a previous study by Johnson et al. (16).

\section{Conclusions}

Our study, which was performed as a pilot in our Center, added to the evidence that shows improved outcomes of fistula tract occlusion by an absorbable fistula plug in fistula-in-ano patients who have prior experience of unsuccessful surgical operation for treatment of this condition. It highlights the importance of infection control in the successful management of the disease by the plug technique. MRI confirmation of healing as a potential adjunct could be used to determine any further work.

\section{Acknowledgments:}

This research received no specific grant from the government or any other funding agency in the public, commercial, or not-for-profit sectors. The author acknowledges the assistance of Dr. Saman Mohamadipour in collecting data and offering constructive criticism of an earlier version of this paper.

\section{Conflict of Interest:}

There is no conflict of interest to be declared.

Authors' contributions:

All authors contributed to this project and article equally. All authors read and approved the final manuscript.

\section{References}

1) Sheikh P. Controversies in fistula in ano. Indian J Surg. 2012; 74(3): 217-20. doi: 10.1007/s12262-0120594-5. PMID: 23730047, PMCID: PMC3397182.

2) Ramanujam PS, Prasad ML, Abcarian H. The role of seton in fistulotomy of the anus. Surg Gynecol Obstet. 1983; 157(5): 419-22. PMID: 6356423.

3) Adler AJ, Ronsmans C, Calvert C, Filippi V. Estimating the prevalence of obstetric fistula: a systematic review and meta-analysis. BMC pregnancy childbirth. 2013; 13: 246. doi: 10.1186/1471-2393-13-246, PMID: 24373152, PMCID: PMC3937166.

4) Lewis RT, Bleier JI. Surgical treatment of anorectal crohn disease. Clin Colon Rectal Surg. 2013; 26(2): 90-9. doi: 10.1055/s-0033-1348047, PMCID: PMC3709961.

5) Ommer A, Herold A, Joos A, Schmidt C, Weyand G, Bussen D. Gore BioA Fistula Plug in the treatment of high anal fistulas--initial results from a German multicenter-study. Ger Med Sci. 2012; 10: Doc13. doi: 10.3205/000164, PMCID: PMC3440842.

6) Herreros MD, Garcia-Arranz M, Guadalajara H, De-La-Quintana P, Garcia-Olmo D, Group FC. Autologous expanded adipose-derived stem cells for the treatment of complex cryptoglandular perianal fistulas: a phase III randomized clinical trial (FATT 1: fistula Advanced Therapy Trial 1) and long-term evaluation. Dis Colon Rectum. 2012; 55(7): 762-72. doi: 10.1097/DCR.0b013e318255364a, PMID: 22706128.

7) Garcia-Olmo D, Herreros D, Pascual I, Pascual JA, Del-Valle E, Zorrilla J, et al. Expanded adipose-derived stem cells for the treatment of complex perianal fistula: a phase II clinical trial. Dis Colon Rectum. 2009; 52(1): 79-86. doi: 10.1007/DCR.0b013e3181973487, PMID: 19273960.

8) Kelly ME, Heneghan HM, McDermott FD, Nason GJ, Freeman C, Martin ST, et al. The role of loose seton in the management of anal fistula: a multicenter study of 200 patients. Tech Coloproctol. 2014; 18(10): 915-9. doi: 10.1007/s10151-014-1186-0, PMID: 24989839.

9) Cestaro G, De Rosa M, Gentile M. Treatment of fistula in ano with fibrin glue: preliminary results from a prospective study. Minerva Chir. 2014; 69(4): 225-8. PMID: 24987970. 
10) Maralcan G, Baskonus I, Gokalp A, Borazan E, Balk A. Long-term results in the treatment of fistula-in-ano with fibrin glue: a prospective study. J Korean Surg Soc. 2011; 81(3): 169-75. doi: 10.4174/jkss.2011.81.3.169, PMCID: PMC3204547.

11) Zmora O, Neufeld D, Ziv Y, Tulchinsky H, Scott D, Khaikin M, et al. Prospective, multicenter evaluation of highly concentrated fibrin glue in the treatment of complex cryptogenic perianal fistulas. Dis Colon Rectum. 2005; 48(12): 2167-72. PMID: 16258708.

12) van Koperen PJ, Bemelman WA, Bossuyt PM, Gerhards MF, Eijsbouts QA, van Tets WF, et al. The anal fistula plug versus the mucosal advancement flap for the treatment of anorectal fistula (PLUG trial). BMC surgery. 2008; 8: 11. doi: 10.1186/1471-2482-8-11.

13) Song WL, Wang ZJ, Zheng Y, Yang XQ, Peng YP. An anorectal fistula treatment with acellular extracellular matrix: a new technique. World journal of gastroenterology. World J Gastroenterol. 2008; 14(30): 4791-4. doi: 10.3748/wjg.14.4791, PMID: 18720541, PMCID: PMC2739342.

14) Chan S, McCullough J, Schizas A, Vasas P, Engledow A, Windsor A, et al. Initial experience of treating anal fistula with the Surgisis anal fistula plug. Tech Coloproctol. 2012; 16(3): 201-6. doi: 10.1007/s10151012-0810-0, PMID: 22527917.

15) Ratto C, Litta F, Parello A, Donisi L, Zaccone G, De Simone V. Gore Bio-A® Fistula Plug: a new sphincter-sparing procedure for complex anal fistula. Colorectal Dis. 2012; 14(5): e264-9. doi: 10.1111/j.1463-1318.2012.02964.x, PMID: 22288601.

16) Johnson EK, Gaw JU, Armstrong DN. Efficacy of anal fistula plug vs. fibrin glue in closure of anorectal fistulas. Dis Colon Rectum. 2006; 49(3): 371-6. PMID: 16421664.

17) Azizi R, Mohammadipour S. New Techniques in Anal Fistula Management. Ann Colorectal Res. 2014; 2(1): e17769. 